\title{
The Gap between Higher Business Education and Business Expectations: The Case of Poland
}

\author{
Małgorzata Tyrańska ${ }^{1}$ D, Mariusz Łapczyński ${ }^{2}$, Maciej Walczak ${ }^{3}$ and Bernard Ziębicki ${ }^{3, *(D)}$ \\ 1 Department of Labor Resource Management, Cracow University of Economics, 31-510 Cracow, Poland; \\ malgorzata.tyranska@uek.krakow.pl \\ 2 Department of Market Analysis and Marketing Research, Cracow University of Economics, \\ 31-510 Cracow, Poland; mariusz.lapczynski@uek.krakow.pl \\ 3 Department of Organization and Management Methods, Cracow University of Economics, \\ 31-510 Cracow, Poland; walczakm@uek.krakow.pl \\ * Correspondence: ziebicki@uek.krakow.pl
}

Citation: Tyrańska, M.; Łapczyński, M.; Walczak, M.; Ziębicki, B. The Gap between Higher Business Education and Business Expectations: The Case of Poland. Sustainability 2021, 13, 13809. https://doi.org/10.3390/su 132413809

Academic Editors: Carmen

Solís-Espallargas,

Dolores Limón-Domínguez,

Jorge Ruiz-Morales and

Rocío Valderrama-Hernández

Received: 28 October 2021

Accepted: 9 December 2021

Published: 14 December 2021

Publisher's Note: MDPI stays neutral with regard to jurisdictional claims in published maps and institutional affiliations.

Copyright: () 2021 by the authors. Licensee MDPI, Basel, Switzerland. This article is an open access article distributed under the terms and conditions of the Creative Commons Attribution (CC BY) license (https:// creativecommons.org/licenses/by/ $4.0 /)$

\begin{abstract}
Employers expect business school graduates to possess a wide and diverse range of competencies, because the conditions governing the operations of enterprises are subject to constant and dynamic change. Therefore, adjusting study programs to labor market requirements is one of the main challenges faced by higher education institutions, particularly business schools. Therefore, the expectations of potential employers have become an object of detailed study for most universities. The most frequently applied research approach adopted for such studies involves direct surveys of employer opinions, based on various types of questionnaires. An alternative method is textual analysis of job advertisements using analytical tools that automate the research process. The aim of this article is to identify the gap between the business education offer and the expectations of the labor market in Poland, as well as to show the possibility of using the analysis of the contents of job advertisements to identify employer expectations regarding the competencies of university graduates. The presented research is exploratory in nature, with four questions posed by the authors during the research process. The research is innovative with regard to Poland and in relation to graduates of business schools.
\end{abstract}

Keywords: business schools; individual competencies; competency gap; text analysis

\section{Introduction}

The adjustment of the educational offer to the expectations of the labor market constitutes one of the main challenges of modern university management. This problem concerns business universities in particular. The conditions of business functioning are undergoing constant changes. All the time, there emerge new challenges related to globalization, ICT development, the sharing economy, innovative business models, and Economy 4.0. As a result, employers expect more and more extensive and diverse competencies from business graduates. This article adopts the British approach to workforce competencies, which is based on the analysis of job requirements and the resulting expectations related to employee competencies, understood as expected knowledge, skills, and attitudes [1-4]. Adjusting the educational offer to the expectations of employers requires a continuous modification of the offered major fields of study, as well as the study programs implemented within them. This implies the need to create a permanent monitoring system of changes related to the competence expectations of employers and to use the results of these analyses to modify the educational offer. The existing approach to monitoring the competencies of university graduates is most often retrospective in nature and is implemented on the basis of reports on the further career development of graduates prepared by career offices functioning at universities [5,6]. This article presents a proposal to enrich the existing approach with a current analysis of employer expectations, carried out on the basis of the analysis of job 
advertisements, thus allowing for quicker identification of important trends emerging in the labor market.

The aim of the article is to identify the gap between the business educational offer and the expectations of the labor market in Poland, as well as to show the possibility of using the analysis of the contents of job advertisements to identify expectations in terms of competencies of university graduates. The research approach presented in the article could be the basis for building an effective system for monitoring changes related to competence expectations in the labor market, used by all universities.

Research on the gap between labor market expectations and provision of business education has already been conducted in various countries. The results of these studies have been published in many scientific articles [7-9]. However, these studies were mostly limited to surveying respondents. They consisted of identifying student competencies and employer expectations on the basis of questionnaires and comparing the results obtained. The approach presented in this article, of identifying competence expectations based on the analysis of the content of job advertisements, is to a large extent innovative. To date, it has been used in a limited number of studies [10-14].

Therefore, this article addresses the research gap in terms of identifying the match between the business educational offer and market expectations in Poland, as well as the gap in terms of methodological aspects of applying textual analysis to job advertisements in order to identify competence expectations. The results of the research and of the methodological proposal presented in the article may be valuable for decision-makers at the level of national authorities as well as for university managers. According to the authors, the obtained results could help to optimize an educational offer that will meet the expectations of all participants in the labor market.

In Poland, a thorough reform of higher education was undertaken in the early 1990s. This was related to the economic transformation that occurred as a result of the transition from socialism to a market economy. As a result of these changes, there was a rapid development of higher education, including business education in particular, which previously was present on a smaller scale and was of marginal importance. Such rapid development led to many problems that, consequently, created a gap between the expectations of the labor market and the educational offer. There were also difficulties in adapting the Polish system of business higher education to the European system, as well as adapting to cooperation with Western universities. The article explains the reasons for these difficulties. The issues regarding developing business higher education in Poland were similar to those experienced by other countries of the former socialist bloc. In this context, the article could be a source of information for comparisons.

\section{Higher Business Education System in Poland}

The systemic transformation that took place in Poland after 1989 brought about profound changes in the country's system of higher education, including in the field of business education [15]. Higher education was decentralized and universities were granted much greater autonomy, which resulted in increased access to tertiary education [16,17]. At the same time, the economic transformation fueled the demand for university graduates. In 1989, the gross enrolment ratio in Polish higher education was below $10 \%$, and less than $7 \%$ of the adult population had completed university degrees [18]. The total number of students attending Polish universities was just 394,000, which translates into a ratio of 102 students per 10,000 people The corresponding ratio for Germany at the time was 300, for the Netherlands, Spain, Ireland and Norway it was 400, for the United States it was 550, and for Canada it was as high as 700 [19]. In terms of the education of its citizens, Poland was ranked 22nd in Europe, just ahead of Albania. By the year 2000, the total number of people in higher education in Poland had reached 1,584,800. The record year for university enrolment was 2005, when the country's total student population reached 1,953,800 [20,21]. From that time on, the student population steadily declined, standing at 1,230,000 in 2019 [22]. This downward trend has been due to two factors: (i) demographic decline and 
(ii) a decrease in the number of extramural (part-time) students. This is reflected in the gross enrolment ratios (GER), which are still at a very high level. In 2005, the ratio was 48.9\%, while in 2019 it was still as high as $46.2 \%$. The record year in this respect was 2010, when the GER in higher education was 53.8\% [22]. The growing interest in higher education resulted in the establishment of new universities, mainly in the private sector. The country's first private university, the Private School of Business and Administration in Warsaw, was founded in 1991. In the academic year 1990/1991, there were 112 universities in Poland, but by 2002/2003 this number had reached 377. In 2020 there were 370 institutions of higher learning in Poland, 240 of which are non-public (mainly private) universities [22].

The economic transformation that accompanied the systemic changes implemented in 1989 also caused a significant increase in the demand for graduates in business studies. In 1990, a mere 24,000 university students in Poland were enrolled in business courses, which constituted $5.9 \%$ of the total student population. In 2005, the record year in terms of the total number of students, 407,800 undergraduates were enrolled in business schools, which translates into $20.87 \%$ of the student population. This means that while there was a five-fold increase in the overall student population between 1990 and 2005, the number of business university students had increased seventeen-fold. In 2019, there were 218,000 business students in Poland, which constituted $18.12 \%$ of the total number of people attending university. The data from 2019 concern a specific subgroup of education courses. i.e., business and administration, in accordance with the International Standard Classification of Education fields introduced in 2013 (ISCED-F 2013). Therefore, these data have a slightly different scope compared to the data used for comparisons of business universities prepared before 2013. Figure 1 presents data on the number of students in the business and administration subgroup (ISCED-F 2013) and the total number of students in Poland in the period 2014-2019.

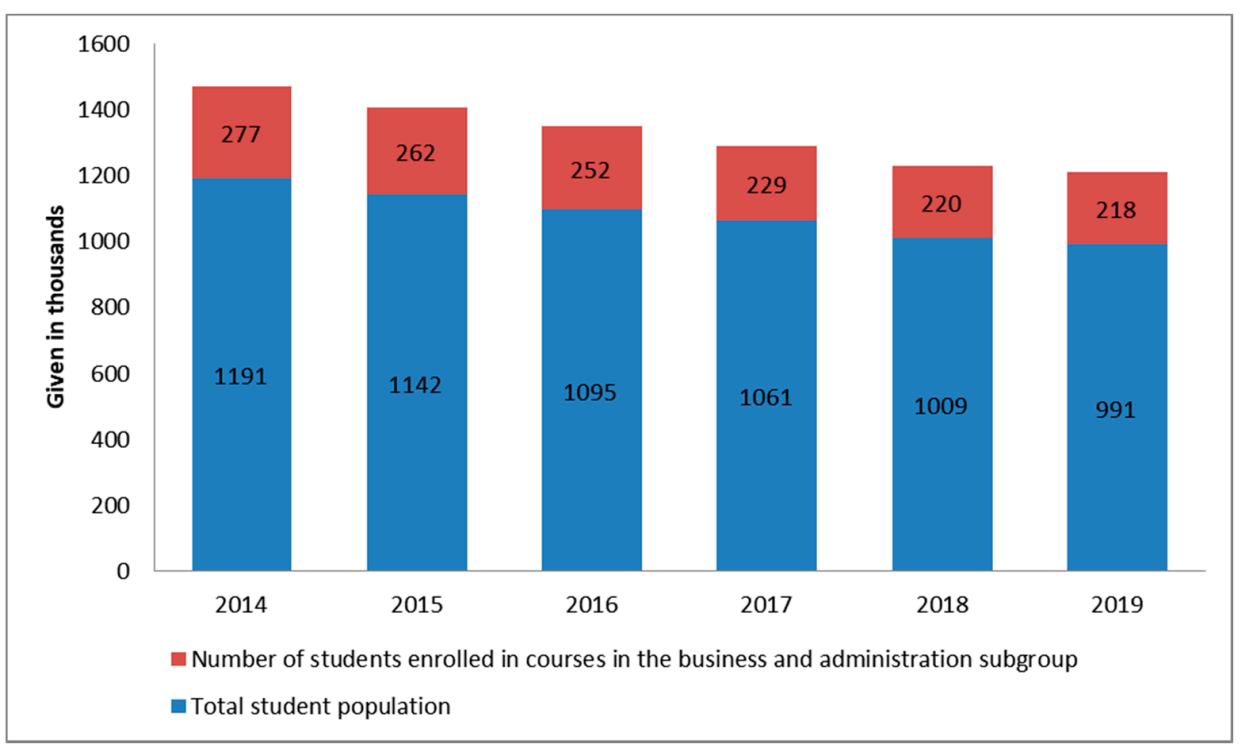

Figure 1. Number of students enrolled in courses from the business and administration subgroup (ISCED-F 2013) compared to the numbers studying other subjects in the period 2014-2019 in Poland. Author's own table based on [22].

The main centers of education for courses and subjects in the business and administration subgroup are state universities of economics located in Cracow, Poznan, Wroclaw, Katowice, and Warsaw, where the Warsaw School of Economics is located. In 2019, a total of 32,365 students [22] were enrolled in business and administration courses at these institutions. Business education is also provided by other state universities, multi-profile universities, and technical universities. However, the largest numbers of students in business and administration are currently enrolled in private universities. 
The rapid increase in the number of both universities and students in Poland in the 1990s resulted in new challenges in terms of the quality of education provided [23]. Universities were expected to meet the growing demands of the labor market by supplying graduates with suitable competencies. As a result, as early as the beginning of the 1990s, a number of institutions were established whose task was to evaluate the quality of education. At that time, the first international accreditations were developed in connection with the need to initiate cooperation between Polish universities and their foreign counterparts, mainly those from the United States and Great Britain. As education became increasingly internationalized, there arose a need to harmonize higher education systems in EU countries. In 1999, the ministers of education of 29 European countries, including Poland, signed the Bologna Declaration, launching the Bologna Process, which became a very important step in international efforts to ensure the quality of education at universities $[10,11]$.

The higher education system currently operating in Poland and reflecting the principles of the Bologna Process, is based on a three-cycle structure of learning. Higher education comprises first-cycle, second-cycle, or long-cycle MA courses. Third-cycle education comprises doctoral studies offered not only by universities but also by scientific institutes, under certain conditions. Degree programs can be either full-time (at least half of the curriculum comprises classes requiring the direct participation of academic teachers and students) or part-time (extramural).

The Bologna Process was a significant factor in the internationalization of Polish universities. However, not all the rules implemented in this area turned out to have positive consequences. In accordance with the principles of the Bologna Process, after completing their first cycle of studies, students may continue their education in any field of study in the second cycle. In most EU countries, the majority of students complete their education after the first cycle. In Poland, due to society's strong attachment to five-year study programs, most graduates of first-cycle studies decide to continue their education into the second cycle. A major challenge facing academic teachers when dealing with students' choices of subjects in the second cycle, which are often not related to the field of study chosen in the first cycle, is how to ensure high-quality education and the expected learning outcomes. Another consequence of the rapid increase in student numbers was a shortage of academic staff. During the period of highest student growth (in the years 1990-2005), the increase in teaching staff was almost a fourth of the growth rate in student numbers [22]. The conditions described above undermined the quality of the education process in Poland's business schools and meant that fewer students met the expectations of the actual business environment. It is this observation that prompted the research presented in this article.

\section{Theoretical Framework}

\subsection{Individual Competencies as an Object of Research}

The topic of competencies has attracted the interest of researchers from various academic disciplines such as psychology, pedagogy, praxeology, law, sociology, and management, which in turn has given rise to multiple definitions of this concept.

The resource-based view constitutes the leading theoretical model in management on which the concept of competence is based. The resource-based view assumes that the success of an enterprise results from the allocation and development of valuable and unique assets (resources) owned or controlled by the given entity [24-29]. Following this assumption, it can be concluded that the competencies of employees (individual competencies) are one of the asset elements that play a key role in achieving and maintaining a company's sustainable competitive position. Competencies are perceived as the abilities needed to make use of resources, primarily intangible ones, in order to build a competitive advantage.

Competencies first began to be considered as a concept in the subject literature in the 1960s and 1970s, as reflected in the publications of White [30] and McClelland [31]. Interest in the subject increased in the 1980s following the publication of Boyatzis' book The 
Competent Manager: A Model for Effective Performance [1]. The author defines "competencies" as characteristics of people that are manifested in effective and/or above-average performance at work. In addition, he highlights those competencies characteristic of the best managers, and divides them into threshold competencies and differentiating competencies. Threshold competencies are defined as necessary for the proper performance of work, while differentiating competencies are typically shown by people achieving above-average results at work.

Although the primary understanding of competencies derived from psychology may be considered precise, in the theory of human capital the concept is understood in various ways. Initially, competencies were treated as a specific cognitive predispositions enabling the absorption of knowledge and the acquisition of skills [32]. Skills represent aptitude and proficiency, and they constitute the relatively enduring ability to apply professional knowledge in a practical manner in order to obtain the desired outcome of an action $[33,34]$. Nowadays, the issue of competencies is the subject of both broad theoretical considerations and empirical research [15-22]. This implies a number of approaches to the concept of competence.

The definitions offered in the subject literature describe competencies in behavioural terms, including the performance of professional tasks. They also link competencies with an individual's job position, indicating that they allow for the performance of professional tasks at the distinguishing level, in accordance with the standards set by the organization. It is worth pointing out that these definitions represent two different approaches to the concept of competence: the American and the British. According to the American approach, a competency is associated with a specific person. This concept, as formulated by Boyatzis [1], focuses on an analysis of people who achieve above-average results, especially with regard to their characteristics such as motives for action, perception of their social role, self-image, skills, and knowledge. On the other hand, in the British approach, developed in 1987 for the National Vocational Qualifications project, a competence is understood in connection with a job position. It also involves a definition of tasks and effects in the context of the requirements related to the performance of a given job. According to this approach, competencies are the properties of work (and not an individual), and the goal is to define the minimum standards for the performance of a given job (rather than focusing on outstanding performers) [3]. Employee competencies are manifested in desired behaviours in the workplace, which enable them to perform professional tasks in accordance with the standards set by the employer and to achieve above-average results in their work. This aspect was also the subject of the research undertaken by the authors of the present article. Teaching and developing competencies through properly prepared study programs is of key importance in the context of the efficiency achieved by graduates in the workplace, and also helps to minimize the competency gap. A competency gap is defined as an insufficient or inadequate level of the competencies that employees must acquire to meet the requirements of their current job [35]. The American Society for Training and Development (ASTD) defines a competency gap as a significant difference between the current capabilities of an organization and the competencies needed to achieve its goals [36]. The competency gap may potentially impede the achievement of a company's planned productivity targets and increase average labor costs, thus adversely affecting the company's profitability [35]. The subject literature identifies three reasons for the existence of a competency gap on a global scale [37]:

- Flaws in the academic system, which does not educate graduates in the basic interpersonal skills and information and communications technology-ICT, which would enable them to adapt quickly to the work environment;

- Rapid and constant technological change;

- Fewer internship or training opportunities in industry that would enable new and existing employees to expand and absorb industry-specific skills.

Lack of cooperation between the business and academic communities can only exacerbate the competency gap [38] and inhibit access to the labor market for business graduates. 
The need for universities and companies to cooperate on the task of preparing curricula and study programs was first mentioned in 2006 [39]. The authors postulated the formation of "knowledge networks" that would integrate the know-how of business experts from the labor market with the innovations of academic staff. As a consequence, study programs would be adapted to the requirements of the labor market on an ongoing basis, in order to improve the employment prospects of graduates [40]. Bridging the gap between business education and the expectations of the business community will help strengthen the relationship between universities and potential employers. In response to the identified competency needs reported by business organizations, economics and management universities recognize the need to reorient their own education systems, study programs, and internship schemes. These reforms are helping to shape the competencies needed and required by the business community and are enhancing the employability of graduates in business studies $[7,41]$.

However, opinions differ in this regard. Some authors wonder whether universities should really follow the requirements of the labor market uncritically, or whether they should focus instead on educating people who would be capable of introducing changes and innovations in this market [42]. They also emphasize the short-sightedness of employers who focus exclusively on the competencies needed in a given time and place. Attention is likewise drawn to the fact that employers overestimate the role of social skills and personality, rather than underestimating the knowledge base in specific fields.

\subsection{Research on Compliance between University Study Programs and the Needs of the Labor Market}

The relationships between the competencies acquired at university and the expectations of employers have been examined by some researchers using questionnaires. For example, Ogata [8] describes research results regarding cohorts of Dutch and Japanese university graduates. In total, interviews were conducted with over 1100 Japanese graduates and over 450 graduates of Dutch universities representing two disciplines: social sciences and engineering and technical sciences. The aim of the study was to show the gap between "university knowledge" and "job knowledge".

A second research approach, based on an analysis of textual data, is precisely the one used in the present study. This approach includes the research results of analyses focused on the content of job openings aimed at university graduates. One of the first uses of text mining to analyze job openings for university graduates was reported in 2007 [10]. The authors downloaded 726 job openings from the popular Italian website www.cambiolavoro.it. Using cluster analysis, they created four relatively homogeneous competence groups, which they called experience, industrial relations experts, internship candidates, and salespersons. To investigate the relationships between competencies they applied association rules and used advanced graphics tools to visualize the results.

In 2017, Y. Kino, H. Kuroki, T. Machida, N. Furuya, and K. Takano [11] published the results of research on job openings adapted to the profiles of people seeking employment. The text data analysis encompassed 15,467 profiles of candidates collected in the period 2010-2016 and referred to, inter alia, as personal data, skills, qualifications, and employment history. The aim of the study was to improve the work of recruiters in employment agencies. The profiles were matched with an employer's address, the financial terms offered, the job title, the job description, and the required competencies. After isolating the keywords, the authors used frequency analysis, hierarchical cluster analysis, and a word coexistence network.

In another study [12], the researchers analyzed the data from the $\mathrm{O}^{*} \mathrm{NET}$ database containing information on the desired skills, abilities, and knowledge of people employed in the United States. The database features over 1000 occupations existing in this country and each of them, regardless of the actual frequency of occurrence on the labor market, was assigned its specific characteristics. The authors explored text data (hidden semantic indexing) and compared the results with job openings found on the Internet. The selection of openings was limited to professions connected with the oil industry and the banking 
and financial sectors. The job advertisements came from Arab countries (UAE, Saudi Arabia, Kuwait, Bahrain, Oman, and Qatar), the United States (Texas, California, Louisiana, Oklahoma, and Pennsylvania), and Great Britain.

A relatively narrowly focused analysis of job openings, limited exclusively to journalism graduates, can be found in a study by C. Marta-Lazo, A.P. González, and C.E. Herrero [13]. In August 2017, a collection of 156 advertisements were downloaded for content analysis from popular websites for job seekers in Spain (Infojobs and LinkedIn). Then, the competencies required by employers were compared with the set of competencies for journalists recommended by the National Agency for Quality Assessment and Accreditation in Spain. The authors noticed a gap between the expectations of the labor market and the study programs prepared for journalism courses.

Another interesting textual exploration of job vacancies was undertaken by A. De Mauro, M. Greco, M. Grimaldi, and P. Ritala [14]. The authors focused on positions connected with big data analysis. Using a web scraper, they downloaded 2786 job openings from Dice.com, which contains over 80,000 vacancies for technical workers. The professions related to the analysis of large amounts of data were categorized into four relatively homogeneous groups: business analysts, data scientists, developers, and engineers. Then, the most common competencies were assigned to each of the groups, which, due to the large numbers involved, were themselves divided into subgroups. The authors listed the following sets: cloud, coding, database management, architecture, project management, systems management, distributed computing, analytics, and business impact. According to the researchers, the results of the analysis may be of use to educational institutions and HR companies providing recruitment services.

The content of online job openings has also been analyzed on the Polish market [9]. In this case, the authors focused primarily on the competencies expected by employers from a dynamic perspective. The data were obtained from over 30 websites featuring job advertisements. Data were collected by automated means during the 2012-2015 time frame at the end of each month. The most common competencies included knowledge of the English language, the ability to work out timelines, meet commitments, and work independently, knowledge of the German language, and attention to detail. Based on their analysis, the authors presented a number of general recommendations for the education system in Poland, while at the same time stressing that the results were mainly useful for jobseekers. They suggested that research of this type should be carried out by research institutes, statistical offices, training institutions, educational policymakers, employment offices, and university career services.

Another example of the application of text mining methods in the study of employee competencies is a study published in 2020 [43]. The authors analyzed the competencies required of Whirlpool employees employed in 68 different positions. Soft and hard skills were divided into four areas: everyday execution, operational tasks, functional tasks, and leadership. Then, a search of the text documents was conducted to detect the presence of keywords connected with Industry 4.0 competencies. These were, among others, predictive analytics, simulation, advanced (smart) manufacturing, real-time computing, SMED (Single Minute Exchange of Die), and mechatronics. On this basis, the authors created competency profiles for all the analyzed positions and determined their compliance with the requirements of Industry 4.0.

The relationship between competencies on the labor market and the requirements of Industry 4.0 was also the focus of interest for another team of researchers [44]. In this case, the textual data concerned six positions from the "associate and mid-senior level management" group, mainly from the United States, Germany, Great Britain, and the Netherlands. A total of 1460 job openings in English were downloaded from LinkedIn between April and July 2018. The authors focused on two areas. The first concerned cyber-physical systems, the Internet of Things (IoT) for automated production, and smart production design and control. The second area was connected with general competencies that were adapted to the requirements of Industry 4.0, e.g., customer satisfaction, enterprise software, 
or supply variable management. On this basis, the authors created eight homogeneous clusters (profiles) of competencies and assigned the analyzed positions to them.

The approach described above, in which competency gap analysis is based on an exploration of the results of job opening analysis, is the subject of the present research.

\section{Materials and Methods}

\subsection{Research Model}

This study should be considered as explorative research, conducted with the aim of addressing four research questions:

Q1: Is business education at universities in Poland adjusted to the expectations of business practice?

Q2: What is the objective scope of business education at universities in Poland?

Q3: What are employer expectations regarding the competencies of business university graduates?

Q4: What benefits and limitations are related to the implementation of text mining tools for identifying the expectations with regard to the competencies of university graduates?

In the initial phase, the research focused on two lines of investigation (Figure 2). The first stage of research involved an analysis of text data obtained from the www.praca.pl (accessed on 10 October 2020) website, and this was used to find answers to research questions Q3 and Q4. According to the information provided by www.praca.pl (accessed on 10 October 2020) itself, the website publishes 30,000 current job advertisements and claims to receive 12 million views per month. In the second research stage, we carried out an analysis of the data provided by the Central Statistical Office, which referred to the numbers of students and graduates in various fields of study at Poland's largest business universities, in order to answer research question Q2.

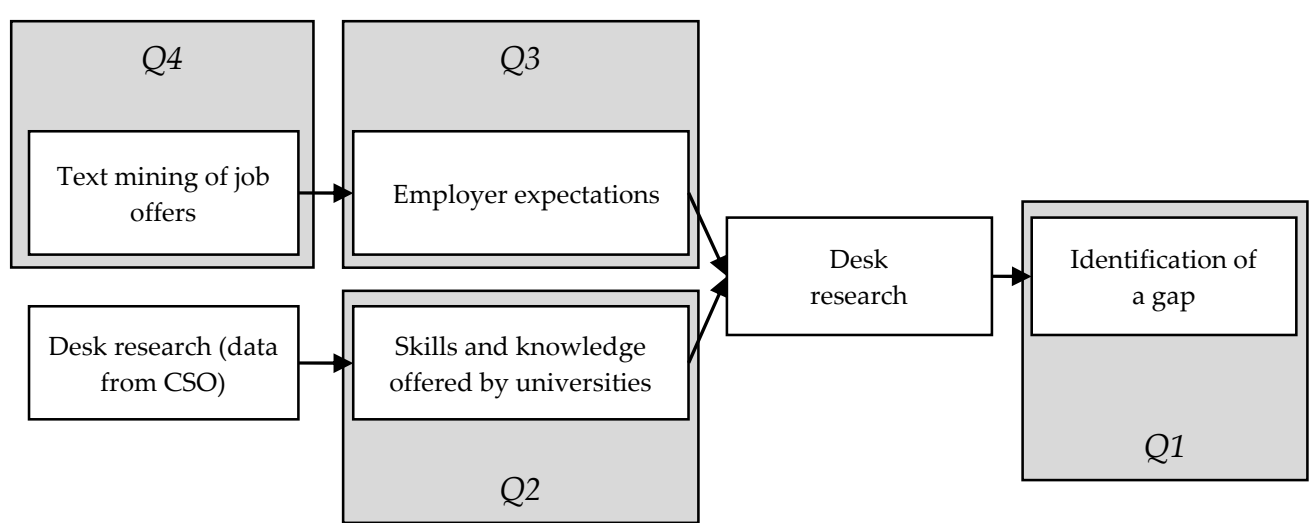

Figure 2. General outline of the research model.

The final stage in the research process was to identify the competence gap of business university graduates, in order to obtain an answer to research question Q1.

\subsection{Data, Materials, and Methods}

The research was based on quantitative and qualitative information such as the number and content of job openings aimed at graduates of business studies and the numbers of students and graduates of business studies at selected universities in Poland.

The primary source of data for the research was the website www.praca.pl (accessed on 10 October 2020), from which the job openings used in the present analysis were downloaded in 2020. The advertisements were collected from the following professional areas: office administration, public administration/civil service, finance/banking, HR/human resources, IT/administration, Internet/e-commerce, quality control, accounting/auditing/taxes, logistics/distribution, marketing/advertising/PR, real estate, environ- 
mental protection, sales/customer service, transport/shipping, and tourism/hospitality. The set of job advertisements is dynamic, which makes it very difficult to obtain data. Advertisements from the beginning of the month may no longer be valid two weeks later and may have been removed from the website. Due to the lack of existing research into the impact of seasonal cyclicality in the numbers of job offers on the Polish market, it was impossible to identify the period in which the number of downloaded text documents would be the highest and thus would facilitate maximizing the retrieval of useful data. Therefore, the data acquisition phase was limited to two weeks in October 2020.

The second source of data was a nationwide list showing the numbers of students and graduates in various fields of study at the largest Polish universities of economics in the 2018/2019 academic year.

The basic research tool applied in the job classification stage was text mining. Analyses based on this method were conducted using WordStat 8.0. To examine the correlation between fields of study in which an education gap was observed and the competencies required by employers, correspondence analysis was used (row and column standardization) [45]. This data mining method facilitates the interpretation of large contingency tables and makes it possible to visualize the results in the form of maps. The authors also made use of basic descriptive statistics, including, in particular, correlation analysis.

\subsection{Research Procedure}

The essential components of the research procedure were an analysis of job advertisements posted on one of Poland's largest recruitment websites (Praca.pl) and an analysis of the study programs offered by the country's largest business universities [22]. The adopted research procedure comprised the stages shown in Figure 3.

Data were extracted from the website www.praca.pl (accessed on 10 October 2020) manually. One barrier impeding automatic text downloading with a web scraper was a lack of standardization in the job openings presented on the website. Some tables had the advantage of rows, and some featured columns that contained information about the requirements for candidates, additional requirements, benefits for people joining the company, or a job description. The order of these sections was not the same and, what is more, not every advertisement contained all the elements mentioned. The requirements set for applicants were formulated by employers in various ways. The following terms were used in the advertisements:

- $\quad$ Because ... you will be ... ;

- What is important for us?

- What do we expect?

- Key competencies;

- Main responsibilities;

- $\quad . .$. are/is welcome;

- Must have;

- ... would be an advantage;

- Expectations;

- We expect;

- You are the person we are looking for, if ... ;

- Requirements;

- The kind of person we are seeking for this role is ... ;

- Required skills/qualifications;

- Your experience and background, etc.; 


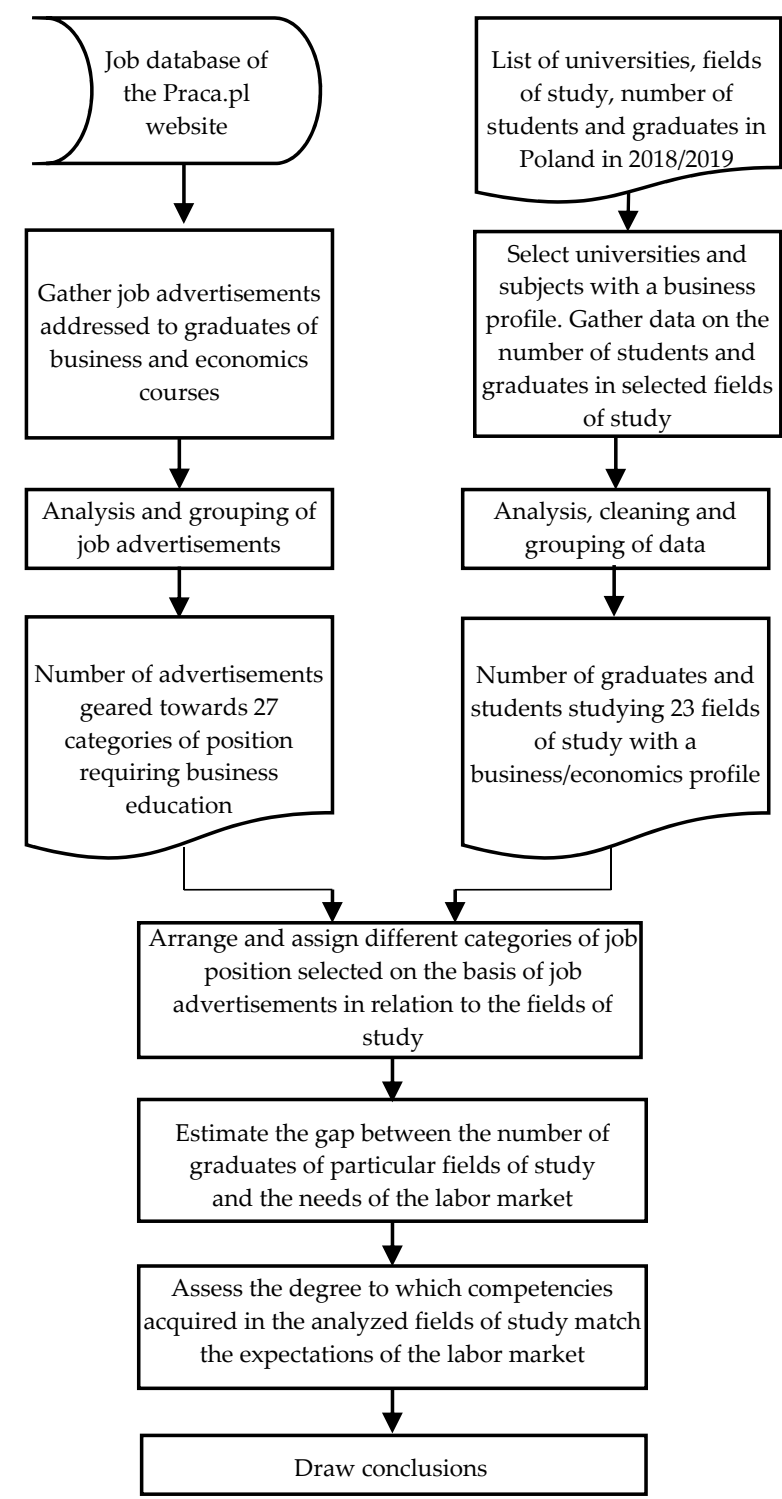

Figure 3. Stages of the research procedure.

Terms in the box in the table containing the job description were:

- As part of the team, you will be responsible for;

- What will you be doing?

- Information about squad;

- If;

- Duties;

- Responsibilities;

- Your role;

- In our team you will be responsible for;

- We are looking for you;

- What you'll be doing;

- You come with;

- Your responsibilities will be;

- What will you be responsible for?

- Tasks;

- Scope of responsibilities;

- Scope of tasks, etc. 
The text data was entered in Excel, which is a popular file format easily imported by analytical programs (in this case: WordStat 8.0). At this stage, the following activities were performed:

- All dashes and hyphens were removed from the text, because the analytical program treats both of these symbols as separating two different words;

- $\quad$ Square and curly brackets were removed from the text, because they are treated in this program as special symbols, e.g., indicating a part of the text that has been excluded from the analysis;

- No lemmatization was performed during the formation of the categories, and stemming was used only for literary categories, e.g., punctual* (for punctuality with all inflectional endings), loyal* for loyalty, and assertive ${ }^{*}$ for assertiveness;

- Duplicate advertisements were removed because duplicate vacancies were a relatively common occurrence. For example, one employer looking for an Internet marketing specialist posted an advertisement in the "marketing, advertising, PR" section and another in the "Internet, e-commerce" section.

Data analysis using WordStat does not require changing the case of letters. The text can be written in uppercase or lowercase. Due to the fact that the job openings were edited in correct Polish form, there was no need to check the spelling (spelling errors were not present in the text).

The purpose of the procedure was to find job openings aimed at graduates of economics universities. The dataset was cleaned by deleting the following:

- Job openings written in English (only Polish-language openings were left, including openings with English job titles);

- Job openings in which an employer was looking for managers, directors, or highly qualified experts (it was assumed that these were not openings aimed at graduates, i.e., people looking for their first job);

- Tenders in which candidates were required to know less-popular languages, e.g., Hungarian, Finnish, or Czech;

- Vacancies for very rare job positions, e.g., customs specialist (number of vacancies, 2), metrology specialist (3), internal control specialist (2), research and development specialist (2), and process optimization specialist (2).

As a result of the data cleaning procedure, the initial 1501 text documents were reduced to 1153. In the next step, the positions were categorized according to the criterion of similarity, e.g., a quality assurance specialist and a quality management specialist in the "quality control specialists" category, or a customer service specialist, a key customer service specialist, a complaints officer, and a corporate customer relations specialist in the "customer service specialists" category. This resulted in the creation of 27 job categories.

It should be pointed out that during the analyzed period, no job openings for commodity experts, consulting specialists, offer specialists, packaging and packaging specialists, market analysis and development specialists, statistical assistants, research and certification department assistants, demographers, and organizers of cultural activities were found in the job advertisement database. The possibility that the competencies of these graduates are required for other positions with different job titles cannot be ruled out. A total of 1153 job openings were examined. The contents of the advertisements were analyzed, and the job positions grouped using WordStat 8.0. A list of these job categories together with the number of job advertisements assigned to them is presented in Table 1.

In the next research step, based on a nationwide list of students and graduates of higher education in the 2018/2019 academic year, we prepared a list of fields of study at universities with a business profile [22]. The following universities in Poland were selected for the list:

- SGH Warsaw School of Economics;

- Katowice University of Economics;

- Cracow University of Economics; 
- Poznan University of Economics;

- Wroclaw University of Economics.

The list included all public universities of economics in Poland. Technical and general education universities were deliberately omitted, because the number of graduates in business fields of study in those universities throughout Poland is small.

Table 1. Job categories together with the number of job openings assigned to them.

\begin{tabular}{clc}
\hline No. & \multicolumn{1}{c}{ Job Category } & Number of Job Openings \\
\hline 1 & banking and finance analysts & 30 \\
2 & business analysts & 82 \\
3 & administration assistants & 13 \\
4 & accounting and finance assistants & 13 \\
5 & management assistants & 15 \\
6 & Accountants & 57 \\
7 & public administration specialists & 33 \\
8 & administration specialists & 64 \\
9 & market risk specialists & 18 \\
10 & controlling specialists & 19 \\
11 & e-commerce specialists & 53 \\
12 & financial specialists & 35 \\
13 & HR specialists & 120 \\
14 & IT specialists and administrators & 121 \\
15 & quality control specialists & 70 \\
16 & Lean Manufacturing specialists & 5 \\
17 & logistics specialists & 80 \\
18 & PR advertising and marketing specialists & 103 \\
19 & real-estate specialists & 39 \\
20 & customer service specialists & 37 \\
21 & environmental protection specialists & 10 \\
22 & planning specialists & 17 \\
23 & tax specialists & 9 \\
24 & sales specialists & 9 \\
25 & tourism specialists & 25 \\
26 & (debt) collection specialists & 17 \\
27 & purchasing specialists & 59 \\
\hline & Total & 153 \\
\hline & &
\end{tabular}

Then, the 27 selected job categories were assigned to the identified fields of study. The basic assignment criterion was the answer to the question: "graduation in which subjects prepares you to work in positions included in individual job categories?". This approach made it possible to assign job advertisements to the fields of study offered in the surveyed business schools.

\section{Results}

In 2021, 52,413 people were studying at all levels of higher education within the 48 analyzed fields of study. Of these, 18,088 , or approximately $35 \%$ graduated, completing a full cycle of education. In the first stage of preliminary data processing, those fields of study without graduates or students in the year in question (e.g., those recently launched or already shut down) were eliminated, as a result of which the number of fields of study was limited to 34. Then, the fields of study underwent a grouping procedure, which reduced their number to 23. The grouping procedure involved summing the numbers of students and graduates, as well as job openings assigned to fields of study in cases where fields of study are considered to be very similar, such as:

- Tourism, tourism and recreation, and tourism economics;

- Finance and accounting, finance, and managerial finance; 
- Management, organization and management (management studies), organization and management engineering, international management;

- Economics and public administration, administration;

- Applied informatics, business informatics, informatics, Internet of Things applications.

The objective of this procedure was to ensure that the results reflected the actual profile of business graduates. During the course of the analysis, we observed fragmentation in the case of (some) subjects. Clustering also made it possible to clean the data of records featuring a very small percentage of graduates. The results of the grouping stage are presented in Table 2.

Table 2. Fields of study together with the number of students, graduates, and job advertisements (arranged in descending order) for each field of study.

\begin{tabular}{|c|c|c|c|c|}
\hline No. & Subject & Graduates & Students & Advertisements \\
\hline 1 & Finance and accounting & 6661 & 15,435 & 280 \\
\hline 2 & Management & 2965 & 8799 & 579 \\
\hline 3 & International economic relations & 1341 & 3293 & 333 \\
\hline 4 & Economics & 1284 & 3802 & 174 \\
\hline 5 & Accounting and controlling & 855 & 1717 & 280 \\
\hline 6 & $\begin{array}{l}\text { Management and production } \\
\text { engineering }\end{array}$ & 835 & 2632 & 278 \\
\hline 7 & $\begin{array}{l}\text { Quantitative methods in economics and } \\
\text { information systems }\end{array}$ & 512 & 1217 & 304 \\
\hline 8 & Applied informatics & 494 & 2173 & 292 \\
\hline 9 & Logistics & 421 & 1959 & 270 \\
\hline 10 & Public economy and administration & 382 & 739 & 203 \\
\hline 11 & Commodity science & 328 & 725 & 214 \\
\hline 12 & Spatial planning & 328 & 759 & 146 \\
\hline 13 & Tourism and recreation & 281 & 772 & 218 \\
\hline 14 & Economic analysis & 268 & 648 & 165 \\
\hline 15 & $\begin{array}{l}\text { Marketing and marketing } \\
\text { communications }\end{array}$ & 255 & 891 & 284 \\
\hline 16 & Informatics and econometrics & 242 & 863 & 304 \\
\hline 17 & E-business & 147 & 788 & 464 \\
\hline 18 & Commercial law & 141 & 323 & 90 \\
\hline 19 & Data analysis-big data & 139 & 832 & 339 \\
\hline 20 & Entrepreneurship and finance & 85 & 578 & 341 \\
\hline 21 & Health care finance and management & 42 & 82 & 221 \\
\hline 22 & $\begin{array}{l}\text { Global business, finance, and } \\
\text { management }\end{array}$ & 41 & 1121 & 112 \\
\hline \multirow[t]{2}{*}{23} & European studies & 40 & 125 & 77 \\
\hline & Total & 18,087 & 50,273 & 5968 \\
\hline
\end{tabular}

The numerical data provided the basis for determining the Pearson's linear correlation coefficients between the studied variables (Table 3).

Table 3. Coefficients of Pearson's linear correlation between the studied variables.

\begin{tabular}{cccc}
\hline Studied Variables & $\begin{array}{c}\text { Number of } \\
\text { Graduates }\end{array}$ & $\begin{array}{c}\text { Number of Job } \\
\text { Advertisements }\end{array}$ & Number of Students \\
\hline Number of graduates & 1 & - & - \\
Number of job & 0.294 & 1 & - \\
advertisements & 0.984 & 0.359 & 1 \\
Number of students & & & \\
\hline
\end{tabular}

All three linear correlation coefficients indicated a positive association. The linear correlation coefficient between the number of graduates and the number of job advertisements was 0.294 . This value indicates a weak relationship between the variables. A similar 
relationship (0.359) could be observed between the number of students and the number of job openings. As a consequence, a weak correlation was observed in the study between the characteristics demanded of employees by an enterprise and the profile of graduates completing business school studies, as well as the number of students enrolled in courses.

In the next step, we calculated the number of graduates in particular fields of study as a percentage of the total number of graduates and the number of job advertisements assigned to particular fields of study as a percentage of the total number of advertisements. The differences between the calculated percentages allowed us to determine the size of the gap/surplus between the number of graduates of the analyzed fields of study offered by business schools and the market demand for specialists in these fields of study expressed as the number of advertisements (Figure 4). A positive result in the diagram below indicates that there are more advertisements than graduates, while a negative result means there are more graduates than advertisements, and one advertisement may be aimed at graduates from more than one field of study.

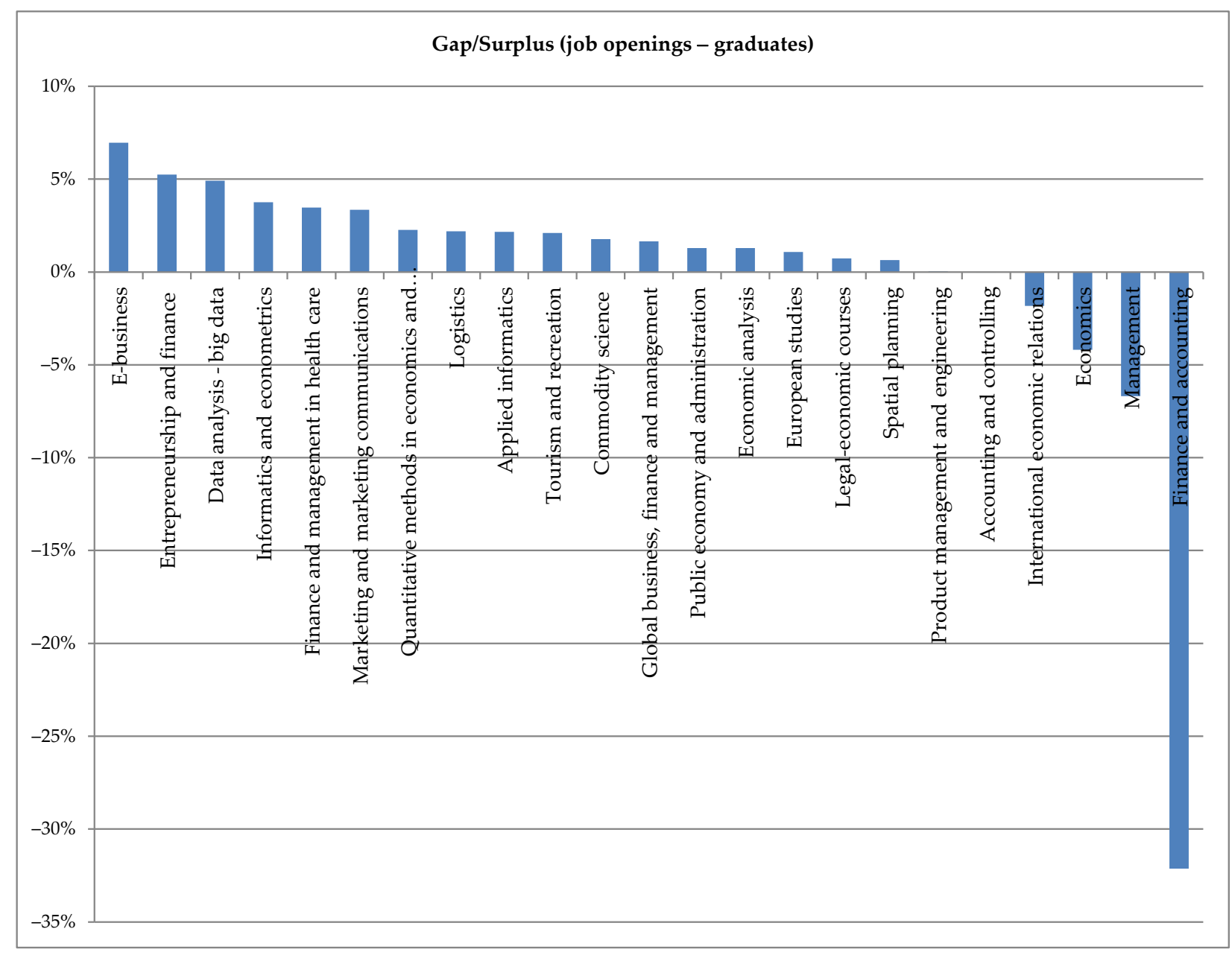

Figure 4. Difference between the number of business graduates and labor market demand (in percentage points).

Another analysis was performed to identify the unique competencies required by employers in graduates of those fields of study which are in the shortest supply in the labor market. The analysis was limited to the first six fields of study, i.e., e-business, entrepreneurship and finance, data analysis-big data, IT and econometrics, finance and management in health care, and marketing and marketing communications. For this purpose, the requirements indicated in job openings aimed at graduates were assigned to the fields of study ( 23 fields of study) covered by the analysis. Unique competencies 
were identified after removing those requirements that were repeated for almost all the fields of study, e.g., knowledge of Microsoft Office, computer skills, or knowledge of the English language. Terms indicating personality traits and competencies acquired outside university education, e.g., independence, commitment, creativity, experience, or having a driving license, were also eliminated. This approach made it possible to analyze the correspondence between the six fields of study and the requirements set for students by employers and draw up a map illustrating these relationships.

Figure 5 shows the coordinate system (map) with row standardization (expected competencies) and column standardization (fields of study). Both the adopted dimensions of the coordinate system explain over $85 \%$ of the inertia (variance).

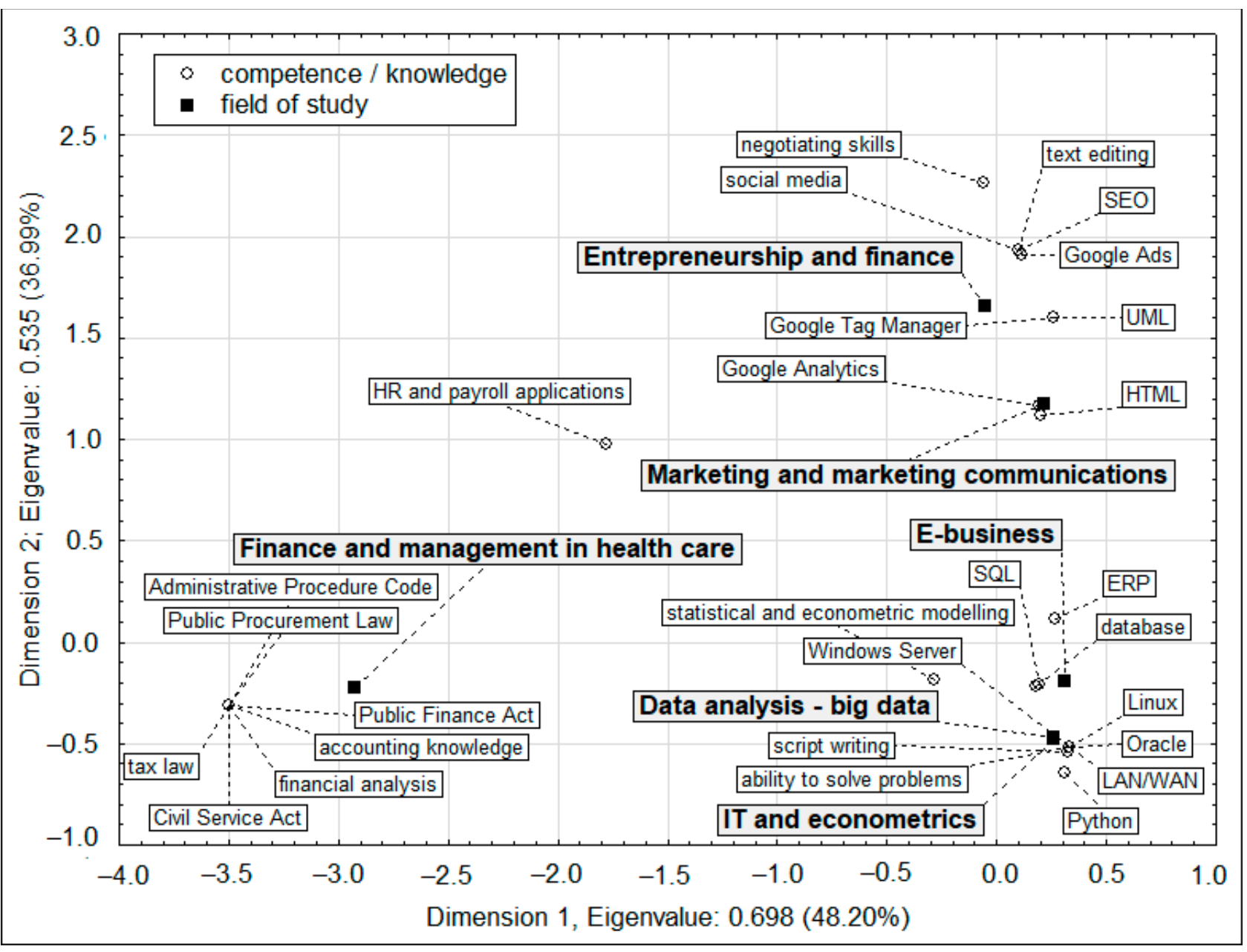

Figure 5. Results of correspondence analysis (row and column standardization).

By comparing the distances between the points representing the fields of study, similarities can be observed between computer science and econometrics, data analysis-big data, and e-business. At the same time, these subjects are different from finance and management in health care (left side of the map) as well as from entrepreneurship and finance (upper right quadrant of the map). The latter field of study is also clearly different from finance and management in health care.

When the distances between the points representing rows are interpreted, three coherent groups of competencies can be seen. Located in the lower left quadrant of the chart are, among others, tax law, the Public Finance Act, accounting knowledge, the Administrative Procedure Code and Public Procurement Law. Located in the lower right quadrant are mainly IT and computational competencies: Python, Oracle, LAN/WAN, script writing, and statistical and econometric modeling. In the upper right quadrant are 
points representing competencies related to web analytics, e.g., Google Analytics, Google Tag Manager, Unified Modeling Language (UML), Google Ads, and social media.

From a formal point of view, the distance between the points representing the rows and the points representing the columns cannot be interpreted. On the other hand, substantive consistency can be observed between competencies and fields of study.

\section{Discussion}

Assessing the degree to which the study programs offered by higher education institutions are in line with expectations of the labor market is a matter of interest to universities all over the world. This problem has become all the more pressing given the increasing competition between universities as a result of globalization, demographic decline in highly developed countries, and decreasing interest in education at universities. Another challenge in this respect is posed by the dynamics of change in the socio-economic environment driven by the development of ICT, new business models, and social transformations. Universities face a growing challenge in their efforts to keep pace with these changes. In such conditions, universities are even being forced to constantly evaluate how well their courses are adapted to the demands of the labor market. As a result, a number of studies have been conducted to identify and then reduce the competency gap [41]. This trend has mainly concerned business schools, i.e., an education sector that has been particularly affected by rapid change. To gauge the extent to which their curricula and courses conform to the expectations of potential employers, universities most often resort to survey methods. However, this type of research is costly and usually provides heterogeneous information. An alternative approach, which has been adopted in the present research, involves analysing the contents of job advertisements. Research of this type has only been conducted recently. The content analysis tools currently available help to significantly automate this process. Moreover, the information thus provided is synthetic.

Referring to the research question Q1, it should be stated that there is a discrepancy between the expectations of the labor market and the educational offer of Polish universities of economics. In practice, this means, on the one hand, that some employers will have a problem finding appropriate employees. This is especially the case with the following business subjects: e-commerce, entrepreneurship and finance, data analysis-big data, IT and econometrics, finance and management in healthcare, and marketing and marketing communication. On the other hand, a certain number of graduates of fields of study such as economics, management, finance, and accounting, will encounter difficulties in finding a job in professions compatible with the field of study they completed. Due to the mismatch between the number of graduates and the needs of the labor market, business schools should shift their admissions priorities away from fields of study in which there is a surplus of graduates in relation to the needs of the labor market towards fields of study with a shortage of graduates from the point of view of employers.

As far as research question Q2 is concerned, a high degree of diversification of the educational offer can be confirmed. This was the case, for example, in the following fields of study: tourism, administration, and international economic relations, which are offered by the Polish business schools analyzed in the study. This state of affairs is due mainly to two factors. The first is the number of students enrolled in Polish universities, which is decreasing each year, largely as a result of demographic decline. The second reason is increasing competition for students between public and private universities. As a consequence of these factors, higher education institutions are stepping up their efforts to make their study programs more attractive and unique and to develop fields of study based on curricula that go beyond the area of business knowledge proper.

Referring to research question Q3, the analysis covered 96 competencies that were present in job offers relating to 27 job categories. This situation has given rise, in certain cases, to discrepancies both in the fields of study taught in these institutions and in the competencies of students attending these courses. The discrepancies present in study programs are clearly reflected in weak correlations in numerical terms both among job 
advertisements addressed to graduates of particular fields of study and between job advertisements and the number of students in particular fields of study. The greatest shortfall in graduates can be observed in such fields of business education as e-commerce, entrepreneurship and finance, data analysis-big data, IT and econometrics, finance and management in health care, and marketing and marketing communications. There is a significant surplus in the number of graduates on the market in finance and accounting. This situation is due to the continuing popularity of this subject over the years among young people, and to the increasing automation of accounting processes, which reduces the demand for specialists in this field. The mismatch in certain fields of business education has, in turn, also given rise to a situation where the competencies acquired in business schools are poorly adjusted to the expectations of the market. The research results indicate that knowledge in the fields of tax law, the Public Finance Act, accounting, the Administrative Procedure Code, and Public Procurement Law is diminishing. On the other hand, a gap exists in the area of typical IT and computational competencies: Python, Oracle, LAN/WAN, writing scripts, or statistical and econometric modeling, as well as in web analytics, including Google Analytics, Google Tag Manager, Unified Modeling Language (UML), Google Ads, and social media.

Referring to research question Q4, it should be stated that the research also confirmed the significant value of analyzing the content of job advertisements using text mining as a method for identifying the competencies expected from university graduates. This method is a much cheaper alternative to survey-based research. It also makes it possible to develop a system that can ensure constant monitoring of changes in competency expectations in the labor market. The limitations of this approach are related to the dynamically changing nature of the analyzed data. Advertisements posted on job portals are frequently subject to changes because they are the result of current business needs.

Previous analyses of employer expectations with regard to job candidates were conducted either with the use of surveys [8] or through textual data analyses [10-14]. The latter method is gaining popularity due to the fact that employers are more and more frequently posting their job offers online. Researchers are keen to use website resources in order to include, e.g., employers all over the country $[10,12]$, websites specializing in technical positions [14] or social networks specializing in professional-business contacts [13,44].

\section{Conclusions}

The conducted research confirmed the existence of a gap between the education provided in Polish business schools and the expectations of potential employers. There are many reasons for this mismatch. The first factor is the rapid pace of change in the work environment in which business education graduates find employment. Secondly, Polish business schools are failing to keep up with these transformations. As a result, the offered study programs, to a great extent, fail to meet the expectations of the labor market. This problem is also largely due to the fact that education in this area has only really been developed over the last 20 years. This, in turn, is a consequence of the systemic transformation that took place in the early 1990s, when Poland's socialist economy was replaced by a free market economy. This triggered a surge in demand for business university graduates. In response, many private business schools were established, while state universities developed numerous business-related courses. The sheer scale and pace of change in this area translated into difficulties in coordinating and controlling these processes. As a consequence, business study programs in Poland are burdened by a wide variety of problems, which often extend beyond the area of business knowledge proper.

The results of the present research may be of use to Ministry of Science and Higher Education policymakers when considering the future development of business schools in Poland. Moreover, they can help rationalize the study programs offered by Polish business schools to ensure they are better adjusted to the current requirements of the labor market. They will also be of value when updating curricula with a view to promoting 
the development of competencies necessary from the point of view of the requirements of potential employers, thereby eliminating the competency gap for business graduates.

The research presented in this study also has certain limitations. The main limitation is its scope, which was restricted to an analysis of advertisements within a specific period of time, collected from one website (Praca.pl). As a consequence, the scope does not allow for any long-term generalizations that apply to all graduates in Poland.

Future research efforts will be dictated by these current limitations. In the future, we plan to conduct a comparative analysis of the job openings posted on the Praca.pl portal in subsequent periods. This research could help to identify the evolving requirements of employers with regard to the competencies of business graduates. In addition, we plan to include data from various other recruitment portals in order to expand the scope of our research. Analyses of individual fields of study, including non-business subjects, is another possible option. International comparative research is another viable research goal.

Author Contributions: Conceptualization, B.Z., M.T. and M.Ł.; methodology, M.Ł. and M.W.; software, M.Ł. and M.W.; validation, B.Z. and M.T.; formal analysis, B.Z. and M.T.; investigation, M.T., M.Ł., M.W. and B.Z.; resources, M.Ł. and B.Z.; data curation, M.Ł. and M.W.; writing-original draft preparation, M.T., M.Ł., M.W. and B.Z.; writing-review and editing, M.T. and M.W.; visualization, M.Ł. and M.W.; supervision, B.Z.; project administration, M.T. All authors have read and agreed to the published version of the manuscript.

Funding: This research was undertaken within the framework of the 'DIALOG' programme of the Ministry of Education and Higher Education (Poland) in the years 2020-2021, Contract No. 0054/DLG/2019/10.

Informed Consent Statement: The research, which are related to the results presented in this article, were conducted with the use of publicly available data, without the direct participation of humans.

Data Availability Statement: The data that support the findings will be available at https://uekkra kowpl-my.sharepoint.com/:f:/g/personal/walczakm_uek_krakow_pl/EoYqGD-1vTFFmiTNxRxsM bEBDqGyWzICWpRMjthyJeWzRA.

Conflicts of Interest: The authors declare no conflict of interest.

\section{References}

1. Boyatzis, R. The Competent Manager: A Model for Effective Performance; Wiley: New York, NY, USA, 1982; ISBN 0-471-09031-X.

2. Explaining the National Qualifications Framework. Available online: https://www.gov.uk/guidance/national-professional-qual ifications-framework (accessed on 21 November 2021).

3. Tyrańska, M. Koncepcja Systemu Oceny Kompetencji Kadry Menedżerskiej w Przedsiębiorstwie; Wydawnictwo Uniwersytetu Ekonomicznego: Kraków, Poland, 2015; ISBN 978-83-7252-699-1.

4. Szadkowski, K. The University of the Common: Beyond the Contradictions of Higher Education Subsumed under Capital. In The Future of University Education; Springer International Publishing: Cham, Switzerland, 2017; pp. 39-62. Available online: https://www.researchgate.net/publication/316516315_The_University_of_the_Common_Beyond_the_Contradiction S_of_Higher_Education_Subsumed_under_Capital (accessed on 21 November 2021).

5. Klimas, P. Kompetencje Absolwentów w Pracy Zawodowej. In Kompetencje Absolwentów Studiów Ekonomicznych. Perspektywa Nauki i Biznesu; Jędralska, K., Bernais, J., Eds.; Wydawnictwo UE Katowice: Katowice, Poland, 2011; pp. $259-271$.

6. Sarin, C. Analyzing Skill Gap between Higher Education and Employability. Res. J. Humanit. Soc. Sci. 2019, 10, 941. [CrossRef]

7. Gomes, C.F.; Yasin, M. Challenges to Business Education: The Gap between Practices and Expectations. Int. J. Bus. Res. 2011, 11, 169-178.

8. Ogata, N. Competencies Acquired at University and Required in the Workplace. In Competencies, Higher Education and Career in Japan and the Netherlands; Springer: Dordrecht, The Netherlands, 2007; pp. 51-76.

9. Pater, R.; Szkola, J.; Kozak, M. A Method for Measuring Detailed Demand for Workers' Competences. Economics 2019, 13. [CrossRef]

10. Di Meglio, E.; Grassia, M.G.; Misuraca, M. The Ideal Candidate. Analysis of Professional Competences through Text Mining of Job Offers. In Effectiveness of University Education in Italy; Physica-Verlag HD: Heidelberg, Germany, 2007; pp. $261-275$.

11. Kino, Y.; Kuroki, H.; Machida, T.; Furuya, N.; Takano, K. Text Analysis for Job Matching Quality Improvement. Procedia Comput. Sci. 2017, 112, 1523-1530. [CrossRef]

12. Karakatsanis, I.; AlKhader, W.; MacCrory, F.; Alibasic, A.; Omar, M.A.; Aung, Z.; Woon, W.L. Data Mining Approach to Monitoring the Requirements of the Job Market: A Case Study. Inf. Syst. 2017, 65, 1-6. [CrossRef] 
13. Marta-Lazo, C.; González-Aldea, P.; Curiel, E.H. Professional Skills and Profiles in Journalism Demanded by Companies: Analysis of Offers at LinkedIn and Infojobs. Commun. Soc. 2018, 211-228. [CrossRef]

14. De Mauro, A.; Greco, M.; Grimaldi, M.; Ritala, P. Human Resources for Big Data Professions: A Systematic Classification of Job Roles and Required Skill Sets. Inf. Process. Manag. 2018, 54, 807-817. [CrossRef]

15. Wiśniewski, J.; Zahorska, M. Reforming Education in Poland. In Audacious Education Purposes; Springer International Publishing: Cham, Switzerland, 2020; pp. 181-208. Available online: https://link.springer.com/chapter/10.1007/978-3-030-41882-3_7 (accessed on 21 November 2021).

16. Białecki, I.; Dąbrowa-Szefler, M. Polish Higher Education in Transition: Between Policy Making and Autonomy. In Structuring Mass Higher Education: The Role of Elite Institutions; Routledge: England, UK, 2009; pp. 183-201; ISBN 978-0-415-88507-2.

17. CSOP. Higher Education Institutions and Their Finances in 2016; Central Statistical Office: Warsaw, Poland, 2017.

18. CSOP. Statistical Yearbook of the Republic of Poland; Statistical Publishing Establishment: Warsaw, Poland, 1990.

19. Kaczmarczyk, M. Program Uczelnia Liderów Jako Narzędzie Wsparcia Procesów Zarzadzania Jakością Kształcenia i Relacjami z Otoczeniem w Szkole Wyższej; Dom Wydawniczy ELIPSA: Warszawa, Poland, 2020; ISBN 978-83-8017-323-1.

20. Sojkin, B.; Bartkowiak, P.; Skuza, A. Determinants of Higher Education Choices and Student Satisfaction: The Case of Poland. High. Educ. 2011, 63, 565-581. [CrossRef]

21. CSOP. Statistical Yearbook of the Republic of Poland; Statistical Publishing Establishment: Warsaw, Poland, 2006.

22. CSOP. Statistical Yearbook of the Republic of Poland; Statistical Publishing Establishment: Warsaw, Poland, 2020.

23. Kwiek, M. Structural Changes in the Polish Higher Education System (1990-2010): A Synthetic View. Eur. J. High. Educ. 2014, 4, 266-280. [CrossRef]

24. Wernerfelt, B. A Resource-Based View of the Firm. Strateg. Manag. J. 1984, 5, 171-180. [CrossRef]

25. Dierickx, I.; Cool, K. Asset Stock Accumulation and Sustainability of Competitive Advantage. Manag. Sci. 1989, 35, 1504-1511. [CrossRef]

26. Grant, R.M. The Resource-Based Theory of Competitive Advantage: Implications for Strategy Formulation. Calif. Manag. Rev. 1991, 33, 114-135. [CrossRef]

27. Barney, J. Firm Resources and Sustained Competitive Advantage. J. Manag. 1991, 17, 99-120. [CrossRef]

28. Amit, R.; Schoemaker, P.J.H. Strategic Assets and Organizational Rent. Strateg. Manag. J. 1993, 14, 33-46. [CrossRef]

29. Peteraf, M.A. The Cornerstones of Competitive Advantage: A Resource-Based View. Strateg. Manag. J. 1993, 14, 179-191. [CrossRef]

30. White, R.W. Motivation Reconsidered: The Concept of Competence. Psychol. Rev. 1959, 66, 297-333. [CrossRef]

31. McClelland, D.C. Testing for Competence Rather than for "Intelligence". Am. Psychol. 1973, 28, 1-14. [CrossRef] [PubMed]

32. Kocór, M. Nadwyżka Czy Deficyt Kompetencji? Konsekwencje Niedopasowania Na Rynku Pracy; Wydawnictwo Uniwersytetu Jagiellońskiego: Kraków, Poland, 2019; ISBN 978-83-233-4634-0.

33. Katz, R.L. Skills of an Effective Administrator. Harv. Bus. Rev. 1974, 52, 90-102.

34. Gamage, D.T.; Pang, N.S.-K. Leadership and Management in Education: Developing Essential Skills and Competencies; Chinese University Press: Hong Kong, China, 2003; ISBN 978-962-996-054-4.

35. McGuinness, S.; Ortiz, L. Skill Gaps in the Workplace: Measurement, Determinants and Impacts. Ind. Relat. J. 2016, 47, 253-278. [CrossRef]

36. Singh, M.; Sharma, M. Bridging the Skills Gap: Strategies and Solutions. IUP J. Soft Ski. 2014, 8, 27-33.

37. Alshare, K.; Sewailem, M.F. A Gap Analysis of Business Students Skills in the 21st Century a Case Study of Qatar. Acad. Educ. Leadersh. J. 2018, 22, 1.

38. Martz, B.; Hughes, J.; Braun, F. Creativity and Problem-Solving: Closing the Skills Gap. J. Comput. Inf. Syst. 2016, 57, 39-48. [CrossRef]

39. Kessels, J.; Kwakman, K. Interface: Establishing Knowledge Networks Between Higher Vocational Education and Businesses. High. Educ. 2006, 54, 689-703. [CrossRef]

40. Winkel, O. Higher Education Reform in Germany. Int. J. Educ. Manag. 2010, 24, 303-313. [CrossRef]

41. Hernández-March, J.; del Peso, M.M.; Leguey, S. Graduates' Skills and Higher Education: The Employers' Perspective. Tert. Educ. Manag. 2009, 15, 1-16. [CrossRef]

42. Teichler, U. Research on the Relationships between Higher Education and the World of Work: Past Achievements, Problems and New Challenges. High. Educ. 1999, 38, 169-190. [CrossRef]

43. Fareri, S.; Fantoni, G.; Chiarello, F.; Coli, E.; Binda, A. Estimating Industry 4.0 Impact on Job Profiles and Skills Using Text Mining. Comput. Ind. 2020, 118, 103222. [CrossRef]

44. Pejic-Bach, M.; Bertoncel, T.; Meško, M.; Krstić, Ž. Text Mining of Industry 4.0 Job Advertisements. Int. J. Inf. Manag. 2020, 50, 416-431. [CrossRef]

45. Greenacre, M. Theory and Applications of Correspondence Analysis; Academic Press: London, UK, 1983. 